\title{
The Role of the Constitutional Court in Protecting the Rights and Freedoms of Individuals: A Case Study of Jordan
}

\author{
Jehan K. Al-Zubi \\ Faculty of Law, Al-Balqa Applied University, Center campus, Salt- 19117. Jordan
}

\begin{abstract}
Establishing the constitutional court is seen as a key demand for displaying the democratic states. In Jordanian context, the high court as well as the regular courts of justice delivered some various decisions insisting on the judicial review issue on the administrative actions and the law constitutionality. This study aims to identify the constitutional courts' role in protecting the freedoms and rights of individuals. Also, it attempts to provide an indepth analysis of the new constitutional courts in Jordanian Kingdom regarding to its own functions that are being found in the constitution and to provide some oversights that are associated to the constitutionality of regulations and laws in powers, and interpret the constitution' provisions. This research found that the available provisions concerning the court procedures and the followed methods to undertake its own judicial works serving as the protectors in which they strengthen the constitutional court role in promoting the freedoms and rights of individuals. The study also found, for fulfilling these freedoms and rights for individuals some elements have to be highlighted such as the role of lawyers, judges and population' awareness. In addition, the investigation high lighted the main vision behind what has been expected by this new Jordanian constitutional court and other courts with regard to defending human rights' field keeping in mind the contemporary threats facing the entire world that increased among individuals in many places and the fears that their basic human rights could be a subject to the serious violations and attacks.
\end{abstract}

Keywords: Constitutional Court, Jordan, Freedoms, Rights, Citizens

DOI: $10.7176 / \mathrm{JLPG} / 94-15$

Publication date: February $29^{\text {th }} 2020$

\section{Introduction}

The way of protecting citizens' rights and freedoms is always seen as a controversial issue in many countries and more specifically the Arab region. Therefore, the Arab Spring appeared in many Arab countries due to the issues of rights and freedoms of individuals. Jordan is one of these Arab countries and the present study aims to see the main role played by the constitutional court to identify how this protects individuals' rights and freedom. In fact, Jordan was safe regarding the Arab Spring and did not face serious problems such as other Arab neighboring countries e.g., Syria, Egypt, Iraq and so on. However, some movements during this Arab Spring period appeared on the Jordanian ground regarding the policies and constitution structure.

According to Abu-Karaki, Faqir, and Marashdah (2011), the laws and democracy in Jordan are protected by constitutional court in which itforms the democratic society's legal framework as well as the controlling of democracy and judiciary in Jordan. This is considered a critical issue as many attempts are found to outline some correlations between these concepts. In addition, these two concepts play an important role in some respects in protecting the individuals' freedom and rights.

These issues that are associated to the freedom and rights of citizens are deemed not to be an aim by themselves. Point of fact, they are powerful structures which serving people and enabling them in order to live in a peaceful as well as social security under the law's rules and guaranteeing the rights and freedom of citizens either collectively or individually (Klee, 2005). Thus, it could be said that the role of the constitutional courthas a significant core for preserving the basic values of individuals' rights and freedoms.

In this regard, AL-Khatib (2011) indicates that the constitutionality oversight regarding laws that are controlled by constitutional courtsets upas an essentialfactor in the legal state formation that is based on the rules of laws and respects for the citizens' freedoms and rights. This kind of principle is being based on the main fact in which it is that the constitution itself is the fundamental lawsbuildingany country's political and legal systems. Therefore, this constitution is seen to be superior rather than other legislations in a country. Consequently, the constitutional rules can only be repealed or amended by a similar constitutional rule (Toubat, Mahafzah, \&Balas, 2019). Besides, this claim points outthat these legal rules might not be implicitly or explicitly contraries to the rules of constitution whether in their content, objectives, or text. Otherwise, these rules can be deemed as unconstitutional (Bassiouni, n.d. as cited in Toubat et al., 2019).

Monitoring the constitutionality function of these laws is typically entrusted to an independent, specialized, and neutral entity controlling the legislature acts; hence, this kind of entity is deemedas the constitution's true protector in terms of both content and form (Toubat et al 2019). This function, in Jordan, is entrusted by the Jordanian constitutional court.In this vein, theJordanian Constitution Article " 58 " states "A Constitutional Court shall be established by a law and based in Amman and shall be deemed an independent and separate judicial body" 
(Toubat et al 2019, p.17). The present research attempts to study the role of the Jordanian Constitutional Court in protecting the Jordanians' freedoms and rights. It clarifies first the concept and importance of the oversight on the constitutionality of the laws.

Jordan is known to be a constitutional parliamentary monarchy. Also, the King is the state head, the executive, and the commander of all armed forces in the kingdom. The Jordanian constitution separates the powersbetween the legislative and executive branches as well it stresses the judiciary independence (Nasrawin, 2016). The constitution of the Jordanian kingdom, in 1952, was firstlydeclared, however, thisconstitution has been modified more than one time in order to to meet the changing needs of the Kingdom. For example, in 2011, the Jordanian constitution has received the most major revisions, as a reaction due the Arab Spring events in the surrounding region. In that period, a Royal Constitutional Reform Committee (RCRC)was formed by the Jordanian authorities in order to develop some constitutional amendments aimingto reflect among Jordanians the high levels of both legal as well political maturities, to a state that has been built on the unity, equality, and freedom values (Nasrawin, 2013).

the Jordanian King, in his letter, to the RCRCHead, in 2011, requested a revision, which should be comprehensive, to the Jordanian constitution's provisions of 1952 ensuringand strengthening the separation principleregarding the power and confirmingto the Parliament to have a greater autonomy, enhancingthe liberties of civilians, limiting the ability of the government for issuinga temporary laws in the Parliament absence, additionally, enhancing the independenceof judiciaryin a way to establish the statutory High Judicial Council (King Abdullah II Website, 2011). Regarding this constitutional revision in 2011 chapter 8 as a new chapter had beenincluded to the Jordanian constitution creating the Jordanian Constitutional Court for workingseparately and independently (Nasrawin, 2016).

According to Abu Hjaileh (2004) in all courts, judges assumed that as a part of their own duty aiming for the sake of protecting the individuals' freedoms and rights that the constitution guarantees. In fact, these judgesdo not have the ability in declaring regulations or laws as void and null, however, they mightbe prevented from conducting some laws found un-constitutional, although the parties of non-constitutionality issuehad not been raised, and these decisions did not carry precedential value (Abu Karaki, Faqir\&Marashdah, 2011).

The constitutional court was established, in Jordan, as an independent judicial body. It was constitutionally assigned with the power to bring some regulations and laws that were not constitutional issuingthe judgments, which were considered final and joining the authorities as well as individuals of the country (Nasrawin, 2016). In other words, the maingoalfor establishing the constitutional court in Jordan is to provide an access to the justice as well for defining the individuals and the country authorities' relationshipin happens after and before using the powers of government. When these legislative powers are being used by the executive branch that issues regulations or by Parliament which issue ordinary laws, this constitutional court is seen to be empowered in order to study the extent in which these rules are being well-suited with the constitution's provisions. Then, any proposed rules can be declaredas unconstitutional and all constitutional courts have toadhere by its findings (Nasrawin, 2016).

However, the constitutional court may issue some interpretations of the constitution based on a request received the Ministers' Council or another majority of either the Senate or the House of Representatives if these governmental powers are being used. These interpretations decisions are deemed as a guide to show how these powers exercised as well as these interpretations are the roadmapsthat depict how resolutions issued to preserve the constitution supremacy and the individuals' freedoms and rights (Al Adayleh,2012).

\section{Research Objectives}

The present study is conducted to achieve the following main objective:

1. To identify the effective role of constitutional court as a factor for protecting the individuals' rights and freedoms in the context of Jordan.

\section{Significance of the Study}

Studying the issue of constitutional court in Jordanian context at this stage as well as the current time has its special significance and this importance is seen regarding some reasons. This kind of study is also deemed to be significant due to its practical and theoretical contributions as well as due to the changes happening in the entire region in which it undoubtedly affects the future stage of the Jordanian country. Hence, this research has its importance in the following two ways:

\subsection{Theoretical Significance}

3.1.1 In fact,the current situation in the entire region is not seen as safe as it should be. In this kind of situation a country needs to enhance its relationship with its own citizens, so there is an important need for such study to observe the situation of the country in order to provide some notes and recommendations.

3.1.2 The stability of a country and feeling of freedom among citizens gives the present study a distinct 
and special form.

3.1.3 Since the Jordanian country has made few changes in the constitution in 2011 in order to guarantee the individuals' freedoms and rights as well as constitutional court was established for this kind of reason, it is important to see its role in protecting these freedoms and rights. In addition, this study is seen to be distinguished as it aims to see the role of this constitutional court in this country and at this time since there are many symptoms for a big war in the region. Furthermore, the study aims to fill the body of knowledge in the politics and law field of study.

\subsection{Practical Significance}

3.2.1 This study practically contributes the Jordanian Kingdom as it highlights essential points in which they encourage policymakers in Jordan to formulate their policies in a way that takes into account the effectiveness of constitutional court role in protecting the citizens' rights and freedoms and provide some recommendations and suggestions regarding the current situations.

\section{The Significance of Studying the Constitutionality of Laws}

Such study aims to see the constitutionality of laws in order to safeguard the supremacy principle of the country constitution that id found as a real guarantor of individuals' freedoms and rights (Ibrahim. 2000). Hence, it is a valuable tool to achieve justice and promote human rights (Nasrawin, 2016; Toubat et al 2019).In other words, the necessity to oversight the laws of constitutionality is seen as follows:

\subsection{Protecting the Constitution Rule and the Democratic System}

Point of fact, controlling the laws of constitutionality is deemed as a pillar to democratic systems in which the democracy needs having the legislative authority's existence in order to undertake the tasksassociated to enacting of laws. In addition, this democracyneeds a judicial body existence to interpret the law's provisions, and to stress that the constitution provisions are not being violated (Abu-Karaki et al., 2011).

These laws are proposed to go along with the country constitution that needs the constitutional court existence to monitoring the constitutionality of these proposed laws. The constitutional court establishment will protect the key principle of the law, also,establishing a democratic countryin which freedoms and rights are respected (Nasrawin, 2016).According to Bugaric (2014)the democracy is not deemed to be effective in a country if it does not have an effective oversight on the laws of constitutionality andsuch oversights must be run by using a constitutional body that is independent to cancel any suggested or seen legislations that are inconsistent with the people's wills.

\subsection{Individuals' Respect for their Own Freedoms and Rights}

Obtaining an oversight regarding the laws of constitutionality verifies that the legislator of a country exercisesthe functions he hasin constitutionally permissible ranges. This kind of act indicates that the legislator must respect individuals' freedoms and rights as the constitution of that country guaranteed these freedoms and rights (Mohammed 2016; Toubat et al., 2019). The Parliament authoritywhile the absence of being subject with regard to the constitutional controls, it is extremely deemeddangerous, since it may drivethe Parliament to enacting a specific law that is not being consistent with the constitution spirit and its own provisions that might violate the freedoms and rights of individuals (Shatnawi, 2001).

All countries' constitutions including Jordanian one, do not address all individuals' freedoms and rights in the same ways. Certain rights are foundas they regulated by laws in which it is enacted by the legislature regarding its discretionary authority. This, in fact, needs to be controlled bythe constitution. This kind of control must be conducted by a specific body that isindependent and specialized. It also has to confirm that such legislature does not exceed the controls of constitutionwhile exercising its discretionary authoritiesto regulate the exercise of individuals' freedoms and rights (Toubat et al., 2019). Therefore, the oversight of the laws of the constitutionality is considered a fundamental and a mainstay protection for the freedoms and rights of individuals, and then, transferring the provisions of the constitution to protect the freedoms and rights of these individuals from the theoretical text to practical reality (Abu-Karaki, et al 2011).

\subsection{Achieving the Legal and Political Stability}

Shatnawi (2001) ensures that the oversight of the laws of constitutionality undoubtedly leads to both legal and political stability in a country, in a place where different views may ariseregarding some provisions of regulations and laws of the constitutionality. In this vein, it is significant to resort to a body having constitutional competences adjudicating this kind of dispute. Therefore, the oversight of the laws of constitutionality avoidsthe legislative chaos as well as the legal stability, also, the disputes' settlement over the rights founded by laws (Makki, 2009). 


\section{Discussion}

According to Toubat et al (2009) due to the disputes may arise in the ordinary courts in which it caused by different laws, regarding this issue, it is essentialfor a country to have a constitutional court in order to determine the constitution meaning linking all available laws to the constitution of this country. Hence, the legal system unity having this kind ofconstitution that stands at itstop is to be maintained correctly, and then, this could achieve the legal stability to the country based on the supremacy's principle of the constitution (Shatnawi, 2001). Thus, the oversight on the laws of constitutionality will lead to both cohesion and unity of the harmony of laws and the legal system with the constitution of the country.

In fact, these actions enable the constitution provisionsof the country being reflected in all available laws making these kinds of laws integral parts of the constitution of the country. In this regard, Bassiouni (n.d) states that the legal systems of a country are diverse in its means, branches as well as protected interests, however, all these systems should be under the constitution umbrella and they should be a subject to uniform the principles of a constitution (as cited in Toubat et al 2019). These ideas highlight the role of constitutional court in any country. Jordan as a special case in this study has to pay attention to these updated rules and see their effects on the individuals. For example, are they welcomed by the population or are they in the benefits of individuals, in other words, do they enhance these individuals' freedoms and rights? All these points should be reconsidered by the government of Jordan.

This above-mentioned idea is supported by Nasrawin (2016) who indicates that the constitutional court faces some challenges in how to responding to the coming changes regarding to the human rights' internationally understanding and definition, additionally, the duties of individuals to their own countries in order to maintain both public orders and national security. For instance, in the United States, a marked shift has been noticed in the people's attitude towardstheir own government due to the judicial review that was established (Schyff, 2010). Lots of pressure has been mounted on the constitutional csourts to accommodatingthe change of the attitudes of publics towards official trials to limitfreedoms and rights regardless of the circumstances.

In this regards, Nasrawin (2016) mentions an always difficulty is seen to be found while determining the limitations between the constitutional court duty toward its own population and duties towards the country. He explains this is determined due to a per-country basis and in accordance to its legislations. Consequently, in some cases, this could createa political opposition, despite in some other cases, a resolution, here, could be available without having conflicts. According to some opponents, they see that a constitutional court has to obtain, in the public life, little roleand the regulationsare deemed to be the ruling party's responsibility in extraordinary as well ordinary circumstances by the legislation and resolution means with having the constitutional court to deal with any challenge (Ginsburg, 2011). As this study aims to identify the role of constitutional court in protecting the freedoms and rights of individuals, it can be stated that this constitutional court could support and protect these rights and freedoms keeping in mind some important factors such as the role of judge, lawyers, and the awareness of public.

\section{Conclusion}

In the Jordanian context, the constitutional court establishment is being welcomed by the legal community with having optimism in this constitutional court. This kind of optimism found the hope that the constitutional court would have an effective judicial rolein protecting individuals' freedoms and rights, enhancing justice, and advancing the law rule in Jordan. Such findings are supported by Nasrawin (2016). In fact, the constitutional court is being established as a public demands' responses with powers to invalidating regulations and laws that oppose constitutions and violate individuals' fundamental freedoms and rights. But, the skeptics argue that the review process of constitution isunnecessarily cumbersome adding that severalconstitutional court law provisions are ambiguous and vague.

Moreover, the lack of the direct access into courts makes thingsmore difficult topeopleas well as the civil societies usingthe judicial review of constitution in a manner that is considered productive and effective one. Based on the above ideas and discussion, this study also find that the constitutional court ability in developing a human rights-oriented and progressive jurisprudence is determined bysome important elements that contain the extent in which the judges are independent while deciding the constitutional matters. Besides, the extentin which ordinary lawyers and judges understand the process of constitution, as well as the level of trust of public and the public knowledge itself in both courts as well as justice systems. In addition, the awareness of public regarding the constitutional court and the likelihood of raising the challenges of constitution in courts in Jordan has to be raised.

Additionally, the Jordanian lawyers' capacity to develop the arguments that are persuasive unconstitutionality, when possible, pursuingthe strategic constitutional litigationshas to be built in order to assist the constitutional court to protect individual' freedoms and rights through the adjudication of constitution. This study recommends further investigation in this field. In fact, more in-depth studies could be suggested as it is an important issue and the idea of study need to include a wider resources and data. 
References

Abu Hjaileh, A. (2004) Scrutinizing the constitutionality of laws in Jordan (pp. 123-125). Amman, JO: Commercial Dastour Press.

Abu-Karaki, M., Faqir, R. S., \&Marashdah, M. A. K. (2011). Democracy \& Judicial Controlling in Jordan: A Constitutional Study. J. Pol. \& L., 4, 180.

Al-Adayleh, A (2012). Al-Wajeez in the Jordanian constitutional system. Amman, JO: Dar Althaqafa.

AL-Khatib, No'man (2011). AL-Wasset (the Mediator) in the Political Systems and Constitutional Law. 7th ed. (Amman: Dar A1 Thaqafa for Publishing and Distribution). ISBN 9957-16-119-9.

Bassiouni, A. (n.d.). Political Systems, Foundations of Political Organization, State-Government-Rights and Public Freedoms.Alexandria :University House.

Bugaric, B. (2014). Protecting democracy and the rule of law in the European Union: The Hungarian challenge. leqs Paper, (79).

Ginsburg, T. (2011).Building reputation in constitutional courts: Political and judicial audiences. Arizona Journal of International and Comparative Law, 28, 539-568.

Ibrahim.P. (2000). Political Systems and Constitutional Law, 3ed. (Alexandria: Manshaat Al Ma'aref).

King Abdullah II Official Website.(2011). Letter to Ahmad Al-Lozi. Retrieved from http://kingabdullah.jo/index.php/ar_JO/royalLetters/view/id/286.html

Klee, H., D. (2005). Training Professionals for Democracy, a paper submitted to a Seminar on the Role of the Media in A Democracy- the Case of Jordan organized by the University of Jordan in cooperation with Konrad Adenauer Foundation. Amman: 27-28 September.

Mohammed. A (2016) "The Requirements of Activating the Supervision of the Constitutionality of Laws under the Constitutional Amendments: (Algeria and Morocco model)." Journal of Law and Society (ASJP).Vol 1, (8), 120-141

Makki, N (2009). Director General of the Federal Supreme Court of Iraq. Philosophical Foundations for the Control of the Constitutionality of Proposed Laws and Constitutional Amendments, Research Paper, University of Baghdad: Center for Strategic Studies.

Nasrawin, L. K. (2016). Protecting Human Rights Through Constitutional Adjudication-Jordan as a Case Study. Digest of Middle East Studies, 25(2), 264-284.

Schyff, G. (2010). Judicial review of legislation: A comparative study of the United Kingdom, the Netherlands and South Africa (p. 8). New York, NY: Springer Science \& Business Media.

Shatnawi, F. (2001). Human Rights And International Humanitarian Law. Study in the International and National Laws. Amman: Dar AL-Hamed for Publishing and Distribution.

Toubat, H. S., Mahafzah, E., \&Balas, H. A. (2019). Oversight on the Constitutionality of Laws: A Case Study of the Jordanian Constitutional Court. JL Pol'y\& Globalization, 82, 17. 